\title{
Den nye europæiske uorden
}

Af Ivan Krastev og Mark Leonard

Annekteringen af Krim har tvunget EU til at se den kendsgerning $i$ øjnene, at dens postmoderne orden ikke kommer til at galde hele kontinentet - for slet ikke at tale om hele verden. Selv om EU stillet over for den russiske aggression har holdt bedre sammen, end dens kritikere mener, har europæerne ikke kunnet samles om en strategi for at bevæge sig ud over den nuværende uorden.

I marts 2014 vågnede europæerne op i Vladimir Putins verden: Et sted hvor grænser kan udskiftes ved magt, hvor internationale institutioner er magtesløse, hvor gensidig økonomisk afhængighed er en kilde til usikkerhed, og hvor forudsigelighed nærmere er et passiv end et aktiv. Den ukrainske krise har tvunget EU til at erkende, at dens idé om en europæisk orden er ophævet. I stedet for osmotisk spredning til at omfatte et kontinent - og måske en hel planet - er Europas postmoderne orden pludselig på tilbagetog.
Nøjagtig som Jugoslaviens sammenbrud sluttede den kolde krigs europæiske orden, markerede krisen på Krim afslutningen på den post-kolde krigs europæiske orden.

\section{Europa som ideal}

Det faktum, at Europa ser sig selv som et ideal for verden, er næppe overraskende. I de sidste 300 år har Europa været centrum for globale anliggender. I 1914 var europæisk orden verdensordenen, skabt af interesser, ambitioner og rivalisering mellem de europæiske imperier. Første Verdenskrig var også kendt som 'den europæiske krig?.

Selvom det i 1919 var den amerikanske præsident Woodrow Wilson, der genindførte orden i verden, var hans vision for global fred hovedsagelig et forsøg på at skaffe orden i Europa. Selv under den kolde krig - da de globale supermagter var ikke-europæiske magter - var ordenen stadig centreret omkring kontrol af Euro-

Ivan Krastev er formand for Centre of Liberal Strategies i Sofia, livsvarigt medlem i Instituttet for humanistisk Videnskab i Wien og medlem af ECFR. Hans seneste bog er 'Democracy Disrupted. The Global Politics on Protest' (UPenn Press, 2014

Mark Leonard er grundlægger og direktør for European Council on Foreign Relations. Han er formand i World Economic Forum's Global Agenda Council on Geoeconomics og forfatter til 'Why Europe Will Run the 21st Century' [Fourth Estate, 2005) og 'What Does China Think?' (Fourth Estate, 2008). 
pa og kappestriden mellem demokratisk kapitalisme og Sovjet-kommunisme som en krig mellem europæiske ideologier.

Det var ikke før 1989-91, at en europæisk model for international ageren opstod, baseret på et sæt postulater og praktikker, der radikalt var forskellige fra den globale orden. I august 1989 knuste de kommunistiske magthavere i Kina den pro-demokratiske bevægelse. I Europa samme år indvilligede de herskende kommunister i en fredelig overgivelse af magten og afslog at bruge militær magt som et legalt politisk instrument.

\section{Farvel til magtbalance}

Det øjeblik holdt Europa sin forskellighed fra resten af verden i hævd. "Det der sluttede i 1989", skrev den britiske diplomat Robert Cooper og opsummerede den nye situation, "var ikke bare den kolde krig og heller ikke engang Anden Verdenskrig. Det der sluttede i Europa (men måske kun i Europa) var tre århundreders politiske system: Magtbalancesystemet og den imperialistiske trang".

Hovedelementerne i denne nye europæiske orden var et veludviklet system af fælles indblanding $\mathrm{i}$ hinandens interne affærer og sikkerhed baseret på åbenhed og gennemskuelighed.

Dette nye postmoderne sikkerhedssystem satte ikke sin lid til magtbalance. Det lagde heller ikke vægt på suverænitet eller adskillelse af inden-og udenrigspolitik. Det forkastede brugen af magt som et instrument til at afgøre konflikter og arbejdede for stigende gensidig afhængighed mellem europæiske stater.

Det postmoderne Europa var ikke interesseret $i$ at forandre europæiske grænser eller $i$ at danne nye stater som efter Første Verdenskrig. Det forsøgte ikke at flytte rundt på folk for at sikre disse grænser som efter Anden Verdenskrig. Efter 1989 var Europas ambition til gengæld at forandre selve grænsernes natur ved at åbne dem for kapital, mennesker og gods og idéer og tanker. Den nye europæiske orden var forskellig fra alle forudgående efterkrigstidsordninger.

Den Kolde Krig sluttede uden en fredsaftale eller en sejrsparade. Det blev hyldet som en gensidig sejr for Vesten og det russiske folk. Det skulle også være en transformerende orden. Gendannelsen af Europa kom i skikkelse af udvidede vestlige institutioner, de fleste af dem skabt til en bipolar verden. Tysklands genforening blev idealet for foreningen af Europa. Atlas blev ganske umoderne - de blev erstattet af økonomiske grafer, der dokumenterede den gensidige finansielle og kommercielle europæiske afhængighed og de europæiske nationers velfærd.

Europæerne var bevidste om den særlige karakter af deres orden, men de var også overbeviste om dens universelle karakter. Fra World Trade Organization (WTO) til Kyoto Protokollen og fra International Criminal Court (ICC) til Responsibility To Protect (R2P) syntes europæiske normer at være det dominerende princip. Europæerne var overbeviste om at gensidig økonomisk afhængighed og harmonerende livsstil ville være den altoverskyggende kilde til sikkerhed i morgendagens verden.

Beruset af sin egen forandring og fornyelse blev EU mere og mere løsrevet fra andre magter - og så kun de områder, hvor andre ikke nåede målet for europæiske standarder, i stedet for at prøve at forstå deres forskellige perspektiver. Dette gjaldt EU's naboer, andre stormager så som Kina og endda allierede som USA. Og det europæiske projekts påstand om - på én og samme tid - at være både enestående og 
Russernes annektering af Krim fik pludselig europæerne til at erkende, at skønt EU's politiske model var beundringsværdig, var det usandsynligt, at den blev universel eller bare spredte sig til mange i EU's umiddelbare nærhed.

universel, gjorde det umuligt for europæerne at acceptere alternative integrationsprojekter på deres kontinent.

\section{Europas Galapagos-øjeblik}

Russernes annektering af Krim fik pludselig europæerne til at erkende, at skønt EU's politiske model var beundringsværdig, var det usandsynligt, at den blev universel eller bare spredte sig til mange i EU's umiddelbare nærhed.

Denne oplevelse ligner de japanske teknologiselskabers. For et par år siden opdagede disse selskaber, at selvom Japan lavede de bedste 3G-telefoner i verden, kunne de ikke finde et globalt marked, fordi resten af verden ikke kunne indhente de teknologiske nyskabelser, så de kunne bruge disse 'perfekte' anordninger.

Dette blev kendt som 'Japans Galapagos Syndrom'. Takeshi Natsuno, som underviser på Tokyos Keio Universitet, fortalte New York Times, at "Japans mobiltelefoner er som de endemiske arter som Darwin mødte på Galapagos-øerne - fantastisk udviklede og ganske divergerende fra deres kontinentale slægtninge".

Snarere end at være for store til at kunne fejle var Japans mobiltelefoner blevet for perfekte til at kunne blive en succes.

$\mathrm{Nu}$ er det Europa der står over for sit 'Galapagos-øjeblik'. Det kan være, at Europas postmoderne orden er blevet så avanceret, at den er blevet umulig for andre at følge. Den udviklede sig i et beskyttende økosystem, afskærmet fra den mere muskuløse 'moderne' verden, hvor de fleste mennesker bor.

Efter Krim var europæerne tvunget til at overveje, hvordan de imødegik Ruslands aggression. Men mere udfordrende er de nødt til at forestille sig, hvad en europæisk orden er i dag, hvor Europas universalisme er blevet en form for undtagelse. Er det i dag ikke vigtigere at beskytte Europas skrøbelige omgivelser fra ydre besmittelse end at drømme om at omskabe andre?

\section{Vestens misforståelser}

"Sejrherren føler ingen nysgerrighed", observerede Carl Schmitt. Og det må især være sandt for sejrherrer, som holder af at tro, at ingen er blevet overvundet, ligesom de ikke frygter et tilbageslag.

Under den kolde krig overanalyserede vestlige hovedstæder hver lille oplysning, der slap ud af Kreml, ivrige efter at vide hvordan den russiske hjerne arbejdede. Efter 1989, beskyttet i deres eget postmoderne økosystem, mistede europæerne deres nyfigenhed med hensyn til, hvordan Rusland ser på verden og dets plads i den. Det glippede for dem at forstå intensiteten i Ruslands moralske fordømmelse af den vestligt ledede europæiske orden, fordi man foretrak at se på den russisk-europæiske forbindelse som en 'win-win'-situation. Man kunne ikke forstå, at det, som europæerne så som den bedst mulige orden, var både hyklerisk og usikker for russerne.

Henført af succes glippede det også for EU at fatte, at det, de så som en godmodig - nærmest planteædende - magt, af andre kunne opfattes som en trussel. Europæiske politikere havde overbevist sig selv om, at bag de lukkede døre var Ruslands virkelige bekymring Kina og Islams radikale udbredelse, og at de uendelige klager 
over NATOs udvidelse eller Amerikas antimissilskjold i Europa bare var en form for folkelig underholdning rettet mod et hjemligt publikum.

Annekteringen af Krim viste, at Vesten havde misforstået Rusland på en række punkter.

For det første forvekslede europæerne Ruslands manglende evne til at dæmme op for dannelsen af den ny postkoldkrigs-orden med accept. De forvekslede svaghed med omvendelse. Efter 1989 var det Sovjetunionen og ikke Rusland, der valgte den europæiske model. For de sidste sovjetiske ledere var udvidelsen af det bløde europæiske herredømme og den gensidige økonomiske afhængighed den eneste måde at beskytte deres imperium mod uafhængighedskravet fra de forskellige sovjetiske republikker.

Konfronteret med valget mellem postmodernisme og opløsning valgte præsident Mikhail Gorbatjov postmodernismen og medunderskrev Paris-charteret og dets vision om et fælles europæisk hjem. Det var derfor Sovjetunionen og ikke Rusland, der stiltiende tillod NATO at inkorporere Den Tyske Demokratiske Republik.

Ulig Sovjetunionen var det postsovjetiske Rusland mistænksom over for alle postnationale konstellationer og bekendte sig til et klassisk nittenhundredetals koncept om suverænitet. Hvad der gør Rusland forskellig fra $\mathrm{EU}-\mathrm{og}$ Gorbatjovs Sovjetunion - er dets overbevisning om, at suverænitet ikke er et retsligt begreb, men snarere evnen til at agere. Som Putins chefideolog Vladislav Surkov så rammende sagde, "suverænitet er det politiske synonym for konkurrenceevne." Dette indbefatter økonomisk uafhængighed, militær magt og kulturel identitet.

I 1993 udgav den russiske klassicist og amatørstrateg Vadim Tsymbursky en betydningsfuld artikel under overskriften 'Øen, Rusland'. Ruslands geopolitiske skæbne, argumenterede han, var en $\emptyset$, der bedst kunne overleve ved at befri sig fra Europa. I hans øjne skulle Rusland befri sig for sine 'tre europæiske århundreder' og indse, at dets forsøg på enten at kopiere Europa (hvilket er hans syn på russisk imperialisme) eller at slutte sig til Europa uundgåeligt ville kulminere i en tragedie.

På et tidspunkt hvor globaliseringen destabiliserer verden, skrev han, var Ruslands eneste gennemførlige mulighed at fokusere på landets østlige besiddelser og på dets indenrigspolitiske udvikling. Rusland var for svagt og fragmenteret inden for grænserne til at have succes i en globaliseret verden. I stedet skulle det forsøge at bygge en 'civilisationsstat' eller 'en identitets-fæstning', der nyder godt af den globale økonomi, men hvis indre politik er beskyttet fra ydre indflydelse.

Opbygningen af en sådan stat indelukket i en hård skal har været Putins hovedformål. Han har aldrig været oprigtigt interesseret $i$ at slutte sig til Vesten. Moskva var ikke interesseret $i$ at smelte ind i vestlige værdier, men var ivrig efter at imitere Amerikas internationale opførsel.

\section{Ikke Rusland Inc.}

For det andet antog europæerne, at Ruslands integration i verden ville afføde en konservativ udenrigspolitik. Europæiske ledere og europæisk offentlighed var ofre for tegneserieagtige beskrivelser af Putins elite.

Historier om gennemgribende korruption og kynisme overbeviste Europa om, at Putins elite ville protestere mod alt, der ville bringe deres forretningsinteresser $\mathrm{i}$ fare. Denne vision om et Rusland Inc. viste sig at være forkert. Den russiske eli- 
te er grådig og korrupt, men nogle af dem drømmer også om Ruslands triumferende genkomst på den globale scene.

Mens meget få russere drømmer om en tilbagevenden til sovjetisk kommunisme, længes et flertal nostalgisk efter Sovjetunionens status som supermagt, 'en stat der kunne respekteres'. Den russiske elite har i langt højere grad end den europæiske elite en tendens til at tænke på sin rolle i historien og til at kombinere merkantilisme med messianisme. Putins revisionisme var mere dybtgående end europæerne fattede. For Putin var afslutningen på Sovjetunionen ikke en historisk nødvendighed, men var nærmere forårsaget af sovjetiske lederes uduelighed.

\section{Farverevolutionerne}

For det tredje formåede europæerne ikke at påskønne den psykologiske virkning af 'farverevolutionerne' og den globale finansielle krises effekt på Rusland. Den Orange Revolution i Ukraine var Putins 11. september. Siden da har den russiske præsident anset fjernstyrede gadeprotester som den værste trussel mod hans regime. Kreml er overbevist om, at alle farverevolutioner på postsovjetisk jord, inklusive protester i Rusland, er blevet skabt, sponsoreret og ledet af Washington.

Den finansielle krise fik på den anden side Putin til at tro, at globaliseringen er på tilbagetog, og at en stormagt efter den finansielle krise må have sin egen økonomiske region. Putins handlinger i Ukraine kunne ligne russisk imperial politik i det nittende århundrede, men de er faktisk en del af et verdensomspændende en- ogtyvende århundredes oprør mod globalisering.

Men den altoverskyggende trussel, som Putin frygter, er mod Ruslands politiske identitet, langt mere end mod dets territoriale integritet. Ikke overraskende anser Moskva EU's tilstedeværelse i postsovjetisk område som en ligeså stor trussel som NATO's udvidelse. Kreml er ligeså foruroligede over Vestens forsøg på at forandre Ruslands 'kulturelle kode' som ved udsigten til, at NATO tager kontrol med Ruslands flådebase i Sevastopol.

\section{Fordelen ved styrke}

For det fjerde fejlvurderede Europa fordelen ved styrke. Vestlige analyser, der sammenlignede Vesten og Rusland, var fulde af tal og grafer, som demonstrerede Vestens forspring økonomisk, teknologisk, ja selv med hensyn til militære budgetter.

Men mens det er sandt, at Vesten er stærkere end Rusland, har europæerne overset, hvad David Brooks har kaldt 'de svages oprør'. Ifølge en bemærkelsesværdig Harvard-undersøgelse har den svage side i asymmetriske krige mellem $1800 \mathrm{og}$ 1849 opnået strategiske mål i bare 12 pct. af tilfældene (Styrke målt i antal af soldater og omfanget af ildkraft). I krige mellem 1950 og 1998 derimod opnåede den svage side forbløffende 55 pct. af sine mål.

Den oftest givne forklaring på denne uoverensstemmelse er, at i sidste halvdel af det tyvende århundrede behøvede den svage side ikke besejre eller ødelægge en fjende, men kun holde ud, som regel på hjemlig grund. Den ugunstigt stillede side behøvede kun at ødelægge fjendens ud-

Konfronteret med valget mellem postmodernisme og opløsning valgte præsident Mikhail Gorbatjov postmodernismen og medunderskrev Paris-charteret og dets vision om et fælles europæisk hjem. 
styr og vente på, at den nominelt overlegne modstander mistede de politiske midler til at kæmpe videre. Når det drejer sig om lokale konflikter, er styrke og svaghed svære at måle.

\section{Putins sårbarhed}

Endelig lykkedes det ikke for europæerne at forstå, hvor sårbar Putin følte sig hjemme. Putins kontrakt med borgerne var grundlagt på en konstant forbedring af den almindelige russers materielle velfærd til gengæld for, at borgerne ikke beskæftigede sig med politik. Dette brød sammen under Moskvas mismods-vinter i 2012. Russerne blev politiserede og gik på gaderne i protest. Putin var overbevist om, at Vesten ønskede en forandring i det politiske regime og brugte protesterne i gaderne for at fremme det.

Da Putin først kom til magten svor han, at han ville slippe fri af de internationale finansielle institutioners klør. Han syntes han havde sikret sig uafhængighed, da Rusland betalte sin udenlandske gæld tilbage i 2006 og opbyggede en stor valutareserve.

Men vinterens protester, der fulgte hans tilbagevenden til præsidentembedet, pegede på endnu en sårbarhed. Da medlemmer af eliten rådede ham til at forhandle med de protesterende, besluttede Putin, at den russiske elites kulturelle og økonomiske afhængighed af Vesten udsatte regimet for fare.

Derefter fik 'nationaliseringen' af landets elite førsteprioritet. Putins improviserede ukrainske satsning bliver bedre forklaret af Kremls frygt for regimeforandring gennem fjernstyrede gadeprotester end hans frygt for NATO-udvidelse.

På den måde bliver 'Besæt Krim’ et logisk svar på de protesterende Moskva-borgeres 'Besæt Abai'-bevægelse.
Kremls indenrigspolitik snarere end Ruslands sikkerhedskalkuler er således årsagen til Moskvas udenrigspolitiske revisionisme. Putin var nødt til at tage Krim for at have magten over sin elite. Putin var nødt til at tage Ukraine. Mens Vesten fokuserede på Putins frygt for et liberalt demokratisk Rusland, var hans største frygt at miste Ruslands nationalister, som ikke ville tilgive ham tabet af Ukraine.

\section{Søgen efter en ny orden}

Rusland har ledt efter en ny europæisk orden i over ti år, en der kan sikre regimets overlevelse selv efter Putin. Men det Putin $ø$ nsker af Vesten, er noget, som Vesten er uvillig og ude af stand til at love ham. I 1943 opløste Josef Stalin Den Kommunistiske Internationale for at overbevise de Allierede om, at han prioriterede sejren over Nazityskland højere end Den Kommunistiske Revolution.

Putin har længe håbet på, at Vesten ligeledes ville slutte sin politik om promovering af demokrati. Han vil have et løfte om, at Kreml ikke bliver konfronteret med rasende protester i Moskvas og Minsks gader, og at vestlige regeringer og vestlige medier i stedet for at understøtte protesterne ville fordømme dem. Uheldigvis for Putin er det noget, som Vesten hverken kan love eller levere.

Der er ingen 'Demokratisk Internationale', som spreder budskabet om demokrati på samme måde, som Komintern understøttede den internationale revolution - og det, der ikke eksisterer, kan ikke blive ophævet.

Mere vigtigt er det, at spontane masseprotester vokser både i demokratiske og ikke-demokratiske lande. Vrede borgere er på gaderne rundt om i verden.

I den forstand markerede Kremls krænkelse af Ukraines territoriale integritet 
"Det er umuligt at sige, hvornår systemet vil falde", observerede Putins tidligere rådgiver Gleb Pavlovsky, "men når det falder, vil det falde i løbet af en dag. Og det, der kommer i stedet, vil være en kopi af dette her".

ikke starten på krisen for efterkoldkrigstidens europæiske orden, men sidste akt af en årelang krise. Spørgsmålet er nu, hvad Europa skal gøre konfronteret med denne afvisning? Hvordan skal Europa reagere på det bogstavelige angreb på dets principper og idealer?

\section{Sanktionsfælden}

EU var i sin fulde ret til at pålægge Rusland hårde sanktioner, men faren for Europas sanktioner er ikke, at det ikke vil virke, men at det ender med at fungere for godt. Det er EU's straffende fældes akilleshæl.

Konfronteret med Ruslands annektering af Krim og Kremls rolle i destabiliseringen af det østlige Ukraine er Vestens eneste alternativ at handle med magt. Et svævende svar ville have inviteret til mere aggression fra Moskva og mere opsplitning inden for EU. De, der ser Vestens tavse reaktion over for den russisk-georgiske krig som en af grundene til at Kreml vovede at foretage sit udspil i Krim, har en pointe.

Men jo mere effektive sanktionerne er i svækkelsen af Ruslands økonomi, desto mere vil de underminere EU’s større mål. Mens USA og EU mente, at fælles sanktioner var den bedste fremgangsmåde, har de ingen fælles idé om, hvad de vil opnå. Er sanktionerne et instrument til at presse Rusland til at stoppe med at støtte oprørere i det østlige Ukraine? Vil de medføre, at Rusland trækker sig ud af Krim? Kunne de fremprovokere et regeringsskifte? Vil et svagere Rusland være et mindre aggressivt Rusland?

For øjeblikket ser det ikke ud til, at sanktionerne har haft held med at foran- dre Ruslands opførsel i det østlige Ukraine, og kun få tror, at sanktionerne vil få Rusland til at levere Krim tilbage. Hvis strategien er et regimeskifte vil sanktionerne næppe have held hverken på kort eller mellemlangt sigt. Og selvom det lykkes, vil et post-Putin Rusland da være et provestligt Rusland?

"Det er umuligt at sige, hvornår systemet vil falde", observerede Putins tidligere rådgiver Gleb Pavlovsky, "men når det falder, vil det falde i løbet af en dag. Og det, der kommer i stedet, vil være en kopi af dette her".

Det vil være en stor fejlslutning for europæiske ledere at tro, at de kan ordne problemerne med Rusland på samme måde som de ordnede problemerne med Serbien i 1990'erne. Og det er ikke bare fordi Rusland er en atommagt, men også fordi hovedparten af Ruslands borgere ikke ser deres fremtid som en del af et europæisk projekt.

Paradokset ved russisk isolationisme er, at jo mere effektive sanktionerne er, desto mere vil de underminere EU's langsigtede mål.

Sanktioner vil tydeligvis lette Putins planer for at begrænse Ruslands åbning mod Vesten. I de tidlige 1960'ere rejste Sovjet en mur gennem Berlins centrum for at isolere Østtyskland fra Vesten. Men Putin kan ikke stoppe med at handle med verden, og han kan heller ikke tilbyde en ideologi, der er i stand til at overbevise russerne om, at de i deres ærefulde isolation vil eje fremtiden.

I stedet har Putin brugt et af knebene i sit elskede judo og bestemt sig for at bruge Vestens magt mod den selv. Russiske em- 
bedsmænd, som gennem årene modstod deres præsidents ordre om at repatriere deres penge fra vestlige banker, gør det nu på grund af de vestlige sanktioner.

De økonomiske omkostninger ved sanktionerne vil gøre det muligt for Putin at skjule Kremls økonomiske politiks fiasko. Sanktionerne giver også Putin en undskyldning for at fremme tvungen isolering fra globaliseringen ved at lovgive om nationalisering af internettet, forbyde udenlandsk ejerskab af medier og begrænse rejseaktiviteter.

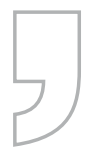

\section{Paradokset ved russisk isola- tionisme er, at jo mere effektive sanktionerne er, desto mere vil de underminere EU's langsigtede mål.}

Yderligere har sanktionerne, der rammer Putins venner, også marginaliseret provestlige medlemmer af den russiske elite. "I tror (i Vesten), at sanktionerne vil splitte eliten og tvinge Putin til at forandre kurs, men det er ikke det, der vil ske", fortalte en hovedrig russisk investor Financial Times. "Tværtimod kvæler I dem i Rusland, som er Vestens venner. Silovikierne (gruppen af Putins håndgangne personer - oftest fra sikkerhedstjenesterne der sidder på den politiske og økonomiske magt, red.) er blevet styrket mere end nogensinde."

Sanktionerne hjælper Putin i hans anstrengelser for at dreje Ruslands handel væk fra Vesten. I en Breugel-artikel udgivet 30. september viser Silvia Merler, at mens udenlandske investeringer fra Europa til Rusland faldt med 63 pct. i de sidste tre kvartaler indtil marts 2014, steg investeringer fra Asien - hovedsagelig Kina - det første kvartal af 2014. Og det er ikke det eneste tegn på, at Rusland har haft en vis succes med at genorientere strøm- men af investeringer. Kinas Nationalbank har også åbnet for kredit for tre af de store russiske banker, som Vesten har pålagt sanktioner.

\section{Faren for militært kapløb}

Der er også en fare for, at sanktioner kunne friste Rusland til at kappes militært med Vesten i stedet for på økonomien. En af den europæiske naboskabspolitiks store ufortalte succeshistorier er, at den med held omformulerede geopolitisk kappestrid i Østeuropa. EU forsøgte at transformere sin periferi gennem økonomisk og social integration. Mens europæisk politik ikke har haft en transformerende effekt på nabolandenes svage politiske liv, omformede den i begyndelsen med held russisk udenrigspolitik.

Efter Den Orange Revolution prøvede Rusland at kappes med Europa i Ukraine og andre postsovjetiske stater ved at bruge sin idé om blød magt (gulerod og pisk; EU-stil politik). Men denne transformation er skrøbelig og vakler allerede. Rusland er mindre tilbøjelig end andre fremvoksende magter til at tænke i økonomiske baner. Det forhold, at Rusland har en ikke-konkurrencedygtig, ensidig økonomi og et magtfuldt militær (den russiske hær har en plan om modernisering af 70 pct. af dets våben i 2020), gør Rusland meget mere tilbøjelig til politiske eventyr end nogen andre af de fremstormende globale magter.

\section{Fort Rusland}

Endelig kunne Vestens sanktioner ende med at fremskynde nedturen for netop det internationale system, som det prøver at holde i hævd. I de sidste par årtier har vestlige magter udøvet politisk indflydelse ved at true med at smide nationer ud af den globale økonomi, som de har 
gjort ved hjælp af sanktioner for at lamme iransk, burmesisk og serbisk økonomi.

Tidligere vestlige kolonier som Indien, Kina og Brasilien bryder sig ikke om måden, hvorpå Vesten har brugt globale institutioner til at fremme egne interesser. Og de er i stigende grad villige og i stand til at omgå globale institutioner ved selv at skabe alternative arrangementer. Fx blev BRICS (Brasilien, Rusland, Indien, Kina, Sydafrika) på det årlige møde i Brasilien enige om at skabe en ny udviklingsbank og valutafond baseret i Shanghai som et klart modstykke til Verdensbanken og Den Internationale Valutafond. Inden for G20 har BRICS dannet et nyt forum for at fremme en antivestlig dagsorden.

Hvis Vesten nu prøver at bruge disse institutioner til at angribe Rusland kan det provokere de fremstormende magter til at slutte sig sammen. På BRICS’ sommermøde i år pressede Putin på for midler til at isolere de fremstormende magter fra Amerikas 'straffende sanktioner' og hindre 'chikanerier over for lande, der ikke er enige' med USA og dets allierede. Så når man skal bedømme effekten af sanktionerne, må Vesten ikke blot se på skaden på den russiske økonomi, men også bekymre sig om de udfordringer, som de måtte afføde for den globale legitimitet af de institutioner, som Vesten selv har bygget.

Sanktionerne kan forære Putin det Fort Rusland, han ønsker, mens det internationale system ryster i sin grundvold. EU vil ikke være i stand til at bringe sammenhæng i sin politik over for Rusland, med mindre det tænker ud over det nuværen- de dødvande og udvikler en klarere vision for den politiske orden, som det søger at opretholde i den omstridte udkant af dets eget postmoderne rum.

\section{Gentænkning af den europæiske orden}

Krisen for den europæiske orden er på mange måder en krise i den europæiske politiske forestillingsverden. Europæere kan ikke begribe, at der findes nationer som ikke kunne drømme om at blive medlem af EU eller at nyde godt af dets regulerede struktur.

Mens Bruxelles har udviklet en begrænset forståelse af det postsovjetiske rum, synes Bruxelles at tale på vegne af civilsamfundet i disse lande, på samme måde som det sovjetiske Kommunistparti plejede at tale på vegne af Vestens arbejderklasse. Det er heller ikke lykkedes for EU at skelne mellem sin magt til at tiltrække og sin magt til at transformere samfund i Europas periferi.

Hvis Kievs Maidan var en magtfuld demonstration af EU's evne til fange borgeres fantasi, har den politiske og sociale udvikling i Bulgarien, Rumænien og på Balkan demonstreret begrænsningen af EU's transformerende kraft.

Den store udfordring i den nuværende krise er, at Bruxelles er nødt til at forestille sig en politik over for Moskva, der ikke har som mål at lave Rusland om til et land som vores, men at udvikle en struktur, der skaber et Rusland vi kan leve sammen med.

Der er nogle brugbare lektioner i den måde hvorpå USA styrer sit forhold til Kina, som Europa kan lære af - en kom-

Den store udfordring i den nuværende krise er, at Bruxelles er nødt til at forestille sig en politik over for Moskva, der ikke har som mål at lave Rusland om til et land som vores, men at udvikle en struktur, der skaber et Rusland vi kan leve sammen med. 
bination af engagement og balancegang. Kina er alt for sammenvævet med det globale system til at blive 'inddæmmet', men det er lysende klart at 'engagement' heller ikke er svaret.

Den amerikanske politiske analytiker Joshua Cooper Ramo har foreslået begrebet 'samudvikling' som en ramme for at begribe dette komplekse forhold. Dette begreb, som først blev beskrevet i Darwins Arternes oprindelse, beskriver situationer hvor to (eller flere) arter gensidigt påvirker hinandens evolution. Ganske passende kunne dette begreb hjælpe Europa til at bevare sin postmoderne Galapagos-orden $i$ en verden, hvor Rusland også forsøger at udvikle sin egen orden.

Selvfølgelig er der betragtelige forskelle mellem EU's forhold til et svækket Rusland og det amerikansk-kinesiske forhold, som omhandler to stormagter, der begge har fornemmelse af, at historien er på deres side. Men ikke desto mindre kunne 'samudviklings'-analogien med Kina være en hjælp for EU til at gentænke den europæiske orden.

'Samudvikling' anerkender, at USA og Kina både er gensidigt afhængige og i konkurrence med hinanden. Det starter med antagelsen om, at disse to stater kan acceptere forskellighederne imellem dem, men også sætte grænser for opførsel, som begge parter finder eksistentielt truende. De engagerer sig med hinanden $i$ en blanding af institutionelle arrangementer (i WTO og G20), men bevæger sig også rundt om hinanden, i SCO (Shanghai Cooperation Organisation) på den ene side og TPP (Trans-Pacific Partnership) på den anden.

\section{Europæisk udgave af 'samudvikling'}

$\mathrm{Nu}$ er det nødvendigt, at EU finder en variant af 'samudvikling', der tillader dem både at sameksistere og sætte gennemførlige grænser for Rusland på et tidspunkt, hvor russiske tropper befinder sig på ukrainsk territorium. Denne kunne have tre vigtige dimensioner: Afskrækkelse og sikkerhedsgaranti for territorial integritet for dens medlemsstater og eksplicit forsvar for staternes territoriale integritet på det europæiske kontinent; omdannelse af den postmoderne EU-model gennem styrkelse af værdibaserede institutioner; og afspænding gennem en politik af anerkendelse af og samarbejde med Den Eurasiske Økonomiske Union, som trådte i kraft den 1. januar 2015.

NATOs topmøde i Wales præsenterede perspektivet for afskrækkelsessøjlen i en mulig samlet EU-strategi. Når det drejer sig om sikkerhed, vil NATO vedblive at være den største garant for sikkerhed i EU's verden - en kendsgerning, der blev bekræftet igen i Wales. Den største udfordring vil fortsat være at overtale Rusland til at afstå fra krigshandlinger i stater, der står uden for NATO.

Etableringen af EU's energiunion og formindskelsen af EU's afhængighed af russisk energi er også en del af Vestens afskrækkelsesstrategi. Men Ruslands krigshandlinger i Ukraine giver den bedste illustration af, at traditionel afskrækkelsespolitik ikke er nok, når den bliver konfronteret med sammenbrudspolitik.

Den anden søjle i en mulig EU-strategi involverer styrkelse og beskyttelse af den postmoderne orden inden for EU. En vigtig del heraf er at skelne mellem 'kerneværdi'-institutionerne i den postmoderne orden (som EU og Europarådet) og 'brobygger'-institutioner, der som OSCE og FN tillader os at engagere os med magter, der ikke deler de samme værdier. Europæiske ledere er nødt til at gøre "kerne'-institutionerne strengere og mere di- 
Rusland er for stort, for vigtigt og for indkapslet i internationale institutioner til, at vi kan håbe på at isolere det på vores egne betingelser. Og endnu vigtigere, Рutin ег ikke bange for isolation, han hilser den velkommen.

sciplinerede og rigide samtidig med, at 'brobygger'-institutionerne gøres mere fleksible og imødekommende.

Ruslands medlemskab af Europarådet har fx ikke resulteret i en 'liberalisering' af Rusland, men i stedet ført til en lammelse af Rådet. Det er lærerigt, at Europarådets parlament ved afstemning vedtog, at der ikke er politiske fanger i Aserbajdsjan. Hvis dette fortsætter, må EU overveje at skride til at suspendere lande som Rusland og Aserbajdsjan.

Dette er ikke en let beslutning at tage, da Menneskerettighedsdomstolen i Strasbourg tilbyder et af de få værn for individuelle menneskerettigheder inden for Ruslands grænser, men EU er nødt til at afveje det i forhold til faren ved den stadige nedbrydning af Europarådets kerneprincipper.

Vi kan og skal bevare idéen om, at en skønne dag vil Den Europæiske Menneskerettighedskonvention være basis for hele Europa (inklusive Rusland og Sydkaukasus). Men det hjælper ikke at lade som om, at det er tilfældet i dag.

Presset for at omdanne værdibaserede institutioner kommer fra Putins 'enevældige demokratis' voksende popularitet hos nogle i EU. Fx har den ungarske premierminister Viktor Orbán erklæret: "Vi leder efter og gør vores bedste for at finde en måde at skilles fra vesteuropæiske dogmer og gøre os uafhængige af dem og finde en form for fælles organisation, der har evnen til at gøre os konkurrencedygtige i det her store verdensræs". For Orbán virker Putin stærk og beslutningsdygtig og europæiske demokratier forvirrede. EU må overbevise Orbán om, at Putins mo- del kan fungere uden for EU, men ikke indenfor, og at det er op til Ungarn at træffe sit valg.

\section{Det fremtidige forhold til Rusland}

Når det drejer sig om det mere langsigtede forhold til Putin, er overvejelserne knap nok begyndt. Vestlige politikere har været stærkt optaget af at presse Rusland til at forandre sin politik i Ukraine. Men hvad kan følgen blive? Og skal vestlig politik over for Rusland begrænses til kun Ukraine? Snakken om 'inddæmning' er blevet almindelig. Men hvad vil inddæmning sige i en verden, hvor vi er gensidigt afhængige af hinanden? Stopper vi med at handle med private russiske selskaber og nedlægger forbud mod russiske turister? Inddæmning lyder lovende men forbliver et hovedbrud.

Vesten kan aldrig anerkende annekteringen af Krim, nøjagtig som Vesten ikke anerkendte Sovjetunionens besættelse af de baltiske stater; og Vesten bliver nødt til bevare sanktionerne på de personer og foretagender, der tjener på besættelsen. Men at blive ved med at opretholde sanktioner i en bred vifte i håbet om, at Rusland en skønne dag vil forandre sin politik og levere Krim tilbage til Ukraine, er heller ikke vejen frem.

Rusland er for stort, for vigtigt og for indkapslet $\mathrm{i}$ internationale institutioner til, at vi kan håbe på at isolere det på vores egne betingelser. Og endnu vigtigere, Putin er ikke bange for isolation, han hilser den velkommen. Ruslands isolation eller selv-isolation er ikke i EU's interesse. Det kunne skærpe nogle af forskellene mellem medlemsstaterne. Det kunne 
indskrænke EU's konkurrencedygtighed på det globale marked. Og det ville også dømme Ukraine til permanent ustabilitet.

Sanktioner var nødvendige for at imødegå Ruslands indtrængen, og de har givet Vesten nogen indflydelse. Denne indflydelse må bruges til at flytte konflikten i Donbas fra slagmarken til forhandlingsbordet. Men når EU endelig kommer til bordet vil det behøve en strategi til at genetablere sin forbindelse med Rusland.

\section{Kernen i krisen}

Denne krise startede på grund af et slagsmål om, hvorvidt Ukraine ville tilslutte sig EU's Østlige Partnerskab eller Ruslands Eurasiske Økonomiske Union (EEU). Paradokset i den nuværende situation er, at det største håb for EU's etablering af forhandlinger med Rusland kunne - efter at Rusland fik Krim og mistede Ukraine være gennem EU's samarbejde med EEU.

Kernen i den nuværende krise er EU's manglende evne til at gribe chancen, der fødtes af Putins EEU-projekt. Etableringen af EEU er en magtfuld manifestation af EU’s bløde magt - et forsøg fra Moskvas side på at vinde status og anerkendelse ved at efterligne EU's institutioner og struktur. Det tilbyder engagement på EU’s vilkår gennem handel og økonomiske forbindelser frem for militær kappestrid.

Skønt rødderne er geopolitiske har EEU fordel af at være omfattet af, men ikke udtrykt i Ruslands etniske nationalistiske sprog, og det er grundlagt på principper om gensidig økonomisk afhængighed. $\mathrm{Nu}$ da Rusland har vendt sig fra Europa, er EEU den slags projekt, som Bruxelles kunne have opfundet, hvis det ikke allerede eksisterede.

Det kunne have været attraktivt for EU, ikke fordi det bliver en succes, men fordi det er det eneste projekt, der kunne aflede
Ruslands opmærksomhed fra militærpolitik og nationalistisk retorik. Men i stedet for at genkende sit eget præg på EEU, blev Bruxelles fornærmet over efterligningen og tabte muligheden for at moderere den kommende konflikt med Rusland.

Hvis EU tilbød udsigt til et samarbejde med EEU, kunne det sende et klart signal til Moskva om, at EU anerkender Ruslands ret til at have sin egen integrationsproces. Det ville vise, at en ny europæisk orden ikke ville blive opbygget omkring en trussel om evindelig udvidelse af EU og NATO. I stedet for ville den blive opfattet som et samarbejde og en konkurrence mellem to integrationsprojekter, baseret på forskellige filosofier, men åben over for dobbelt medlemskab og forskellige former for overlapning og samarbejde.

Det ville demonstrere en ligeværdighed og vise verden, at EU anerkender postsovjetiske staters ret til at vælge det integrationsprojekt, de selv ønsker. Det er EU's villighed til at anerkende Armeniens 'eurasiske valg', der giver Bruxelles ret til at presse Moskva til at acceptere Moldovas og Ukraines europæiske valg.

\section{Tilbage til den økonomiske slagmark}

Selvfølgelig er EEU i de fleste europæeres øjne et anløbent projekt. Men det kunne blive EU's bedste mulighed for at skubbe konkurrencen mellem Rusland og Vesten tilbage til den økonomiske slagmark i stedet for den militære.

Desuden er EEU et interessant indgangspunkt, fordi det i det mindste indebærer en vis bremse på Ruslands politiske beslutningsproces og Kremls magt (alle dets medlemmer - Rusland, Kasakhstan, Hviderusland, Armenien og Kirgisistan har vetoret i alle fælles beslutninger). Midt i en eskalerende konfrontation mellem Rusland og Vesten kunne EU's anerken- 
I 25 år har europæerne prædiket om et genstridigt Rusland og argumenteret for, at det var ude af trit med virkeligheden. Nu er det Eப, der behøver at forholde sig til de hårde kendsgerninger.

delse og samarbejde med EEU hjælpe EU til at udvikle forbindelser med Kasakhstan og Hviderusland.

EEU er selvfølgelig ikke svaret på alt. Men det kunne være begyndelsen til en ny forhandling om en ny europæisk institutionel orden til udfyldelse af tomrummet efter sammenbrudte institutioner, der er forkastet af Moskva.

Rusland har væltet Europas drømme om en fremtid, hvor dets postmoderne ø skulle omfatte kontinentet. Men Europa er endnu ikke tilbage i den kolde krig. Den konfrontation mellem Moskva og Vesten drejede sig om, hvem af dem der kunne tilbyde en 'bedre' verden. Konflikten i dag mellem Rusland og EU drejer sig om, hvem der lever i den 'virkelige' verden.

I 25 år har europæerne prædiket om et genstridigt Rusland og argumenteret for, at det var ude af trit med virkeligheden. Nu er det EU, der behøver at forholde sig til de hårde kendsgerninger. Europa er nødt til at fokusere sin transformerende energi på at konsolidere sit eget politiske råderum, som nu indbefatter Ukraine $\mathrm{og}$ Moldova, og anerkende 'den virkelige verden' uden for sine grænser.

EU kan ikke på nuværende tidspunkt forvente at omforme Rusland, men bør være opmærksom på prisen for at udelukke det. Det er uordenen midt i den nye europæiske orden.

(C) European Council on Foreign

Relations

Oversat fra engelsk af Christiane Rohde 